\title{
COMUNICADOS
}

\section{First report of Alternaria brassicicola on Crambe abyssinica in Goiás state, Brazil}

\author{
Dirceu Macagnan $^{1 *}$, Zuleide Martins Chaves ${ }^{2}$, Adalberto Corrêa Café-Filho
}

\begin{abstract}
${ }^{1}$ Instituto Federal de Educação, Ciência e Tecnologia de Brasília Campus Planaltina. Rod. DF 128 km 21 CEP 73.380-900 Planaltina-DF, Brazil. ${ }^{2}$ Universidade de Brasília, Departamento de Fitopatologia CEP 70.790-900 Brasília-DF, Brazil.

Autor para correspondência: Dirceu Macagnan (dirceu.macagnan@ yahoo.com.br)

Data de chegada: 20/12/2009. Aceito para publicação em: 28/06/2010.
\end{abstract}

The crambe (Crambe abyssinica Hochst. ex Fries; Brassicaceae), is an herbaceous plant with indeterminate flowering, however indehiscent fruits do not fall completely mature (Fontana et al. European Journal of Agronomy 9: 117-126. 1998). In Brazil, it is sown after harvesting the main summer crop, and yields about $1200 \mathrm{~kg} \cdot \mathrm{ha}^{-1}$ of seed having inedible oil content of about $38 \%$. Low water requirement, short crop cycle of about 90 days, rusticity, and the possibility of cultivating between main cropping seasons, has attracted attention for its use as feed stock for biodiesel production. It is estimated that in 2009 the crop was raised on about 10000 ha.

In May 2009, at Rio Verde -GO lower leaves of plants (FMS Brilhante cultivar) showed initially grey necrotic spots (Fig1A), and as the disease progressed, they were covered with concentric zones and encircled with a chlorotic halo. Severely affected leaves showed premature senescence (Fig 1B). Intense dark sporulation was observed on the lesions. The clavate conidia produced on dark elongate conidiophores (Fig. 1C) with transverse and longitudinal septa were formed in chains (Fig. 1D). The fungus was identified as Alternaria brassicicola (Schw.) Wiltshire based on the morphological analysis described by Simmons (Alternaria An identification manual 775p. 2007). The fungus was isolated by transferring the conidia from the lesions to PDA in culture plates. After 3 days incubation at $25{ }^{\circ} \mathrm{C}$, individual colonies were transferred to fresh PDA in plates and incubated again for conidia production. There was intense greenish pigmentation on both side of the colonies, however on the upper surface, the colonies became darker due to abundant sporulation. To test the pathogenicity, a conidial suspension $\left(10^{5} \cdot \mathrm{ml}^{-1}\right)$ was prepared in tap water, and sprayed on crambe plants till run off. Plants sprayed with water only served as control. After spraying, the plants were placed for $12 \mathrm{~h}$ in a moist chamber. Lesions similar to those observed in field were visible after 4 days and the pathogen was recovered from the lesions.

In the Netherlands the Alternaria leaf spot is reported to be caused by $A$. brassicae and more commonly by A. brassicicola (Mastebroek et al. Seed Science and Technology 26: 763-770, 1998). Its is also an important disease of crambe in Canada (Zoebelein et al. Ditionary of renewable resources 408p. 2001), and USA (Kilpatrick, Phytopathology 66: 945-948, 1976). In Australia (You et al. Plant Disease 89:430,2005), Cuba and other Caribbean countries the disease

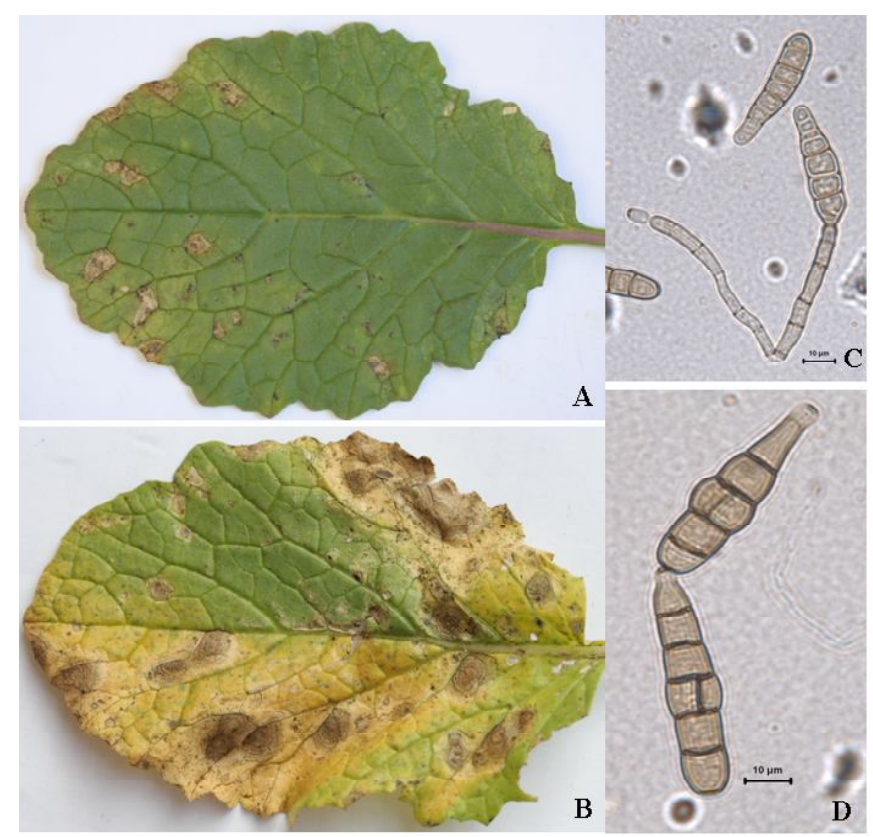

Figure 1: Alternaria leaf spot (A. brassicicola) on leaves of Crambe abysinica. Initial symptoms (A), advanced stage of infection (B). Structures of Alternaria brassicicola on light microscopy showing conidiophores and conidia in formation (C) and conidia on a chain (D).

is attributed to A. brassicae (Minter et al. Fungi of the caribean: An annotaded checklist, 946p. 2001).

In Brazil the disease was first reported from the state of Paraná in 2009 (Carneiro et al. Summa Phytopathologica 35: 154. 2009), and there is no other report of its occurrence in Brazil. This disease is especially important to central region of Brazil, where is located the Goiás state. This disease may cause important losses because this is one of the most important region to production feed stock for biodiesel production, and the crambe is one of the most promising culture. The leaves with symptoms and fungal sporulation have been deposited in the Reference Mycological Collection Herbarium (Coleção Micológica de Referência - Herbário UB) of the University of Brasília (UB 21039). 